\title{
Peran Program Merdeka Belajar Kampus Merdeka dalam Pengembangan Desa Binaan Melalui Edukasi Potensi Bahan Alam Bumbu Dapur Sebagai Terapi Alternatif pada Penyakit Gigi
}

\author{
Atia Nurul Sidiqa ${ }^{1}$, Asih Rahaju ${ }^{2, *}$, Zwista Yulia Dewi ${ }^{1}$, Ratih Widyasari ${ }^{2}$, Hartanto \\ Endrowahyudi ${ }^{2}$, Badi Soerachman ${ }^{2}$
}

\author{
${ }^{1}$ Departemen Material Kedokteran Gigi, Fakultas Kedokteran Gigi, Universitas Jenderal \\ Achmad Yani, Cimahi, Indonesia \\ ${ }^{2}$ Departemen Konservasi Gigi, Fakultas Kedokteran Gigi, Universitas Jenderal Achmad Yani, \\ Cimahi, Indonesia \\ *Penulis korespondensi : asih.rahaju@lecture.unjani.ac.id
}

\begin{abstract}
Abstrak: Mayoritas penduduk Desa Mekarsaluyu memiliki mata pencaharian sebagai petani dan buruh tani. Selain petani, mata pencaharian penduduk Desa Mekarsaluyu adalah pedagang dan tenaga pertukangan. Secara geografis, Desa Mekarsaluyu berada pada jalur wisata. Pandemi global virus Covid-19 telah berlangsung selama 2 tahun, kondisi tersebut menyebabkan masyarakat perlu melakukan beberapa adaptasi dan perubahan perilaku. Kesehatan gigi pun menjadi bagian penting yang harus dijaga kebersihan dan kesehatannya agar sistem kekebalan tubuh kita secara menyeluruh tetap optimal. Gigi dan mulut merupakan pintu gerbang masuknya kuman penyakit. Kehadiran alam sekitar sangat membantu masyarakat yang hidup dari alam. Kesehatan akan terjaga apabila masyarakat tahu bahwa alam sekitar memberikan manfaat kesehatan yang luar biasa. Salah satu contohnya dari mengkonsumsi bahan-bahan yang sering digunakan sebagai bumbu dapur. Pendekatan yang dilakukan pada pendayagunaan peran mahasiswa sebagai implementasi program Merdeka Belajar Kampus Merdeka (MBKM) melalui kegiatan edukasi kepada masyarakat. Program ini dilaksanakan dengan efektif dan efisien karena dilakukan secara berkesinambungan dari hulu ke hilir. Edukasi dengan tema bumbu dapur yang berasal dari alam sekitar sebagai alternatif penanganan masalah kesehatan gigi di Desa Binaan Wilayah Desa Mekarsaluyu Kecamatan Cimenyan, Kabupaten Bandung. Edukasi mengenai potensi bahan alam terutama bumbu dapur sebagai alternatif terapi kesehatan gigi dengan pendekatan melalui metode audio visual pada Ibu-ibu PKK di di Desa Binaan telah berhasil dilakukan dengan antusias dengan minat yang tinggi.
\end{abstract}

Kata kunci: bumbu dapur, desa binaan, edukasi, gigi, kesehatan

\begin{abstract}
The majority of the population of Mekarsaluyu Village have a livelihood as farmers and farm laborers. Apart from farmers, the livelihoods of the residents of Mekarsaluyu Village are traders and carpenters. Geographically, it is on the tourist route. The global pandemic of the Covid-19 virus has lasted for 2 years, this condition causes people to need to make some adaptations and behavior changes. Dental health is also an important part that must be kept clean and healthy so that our overall immune system remains optimal. Teeth and mouth are gateways for germs to enter. The presence of the natural surroundings is very helpful for people
\end{abstract}

Volume 3, Nomor 1, Maret 2022| 59

Peran Program Merdeka Belajar Kampus Merdeka dalam Pengembangan Desa Binaan Melalui Edukasi Potensi Bahan Alam Bumbu Dapur Sebagai Terapi Alternatif Pada Penyakit Gigi

Atia Nurul Sidiqa, Asih Rahaju, Zwista Yulia Dewi, Ratih Widyasari, Hartanto Endrowahyudi, Badi Soerachman

https://doi.org/10.26874/jakw.v3i1.170 
who live from nature. Health will be maintained if people know that the natural surroundings provide extraordinary health benefits. One example is from consuming ingredients that are often used as kitchen spices. The approach taken is to utilize the role of students as the implementation of the Merdeka Belajar Kampus Merdeka (MBKM) program through educational activities for the community. This program was implemented effectively and efficiently because it is carried out continuously from upstream to downstream. Education with the theme of kitchen spices originating from the natural environment as an alternative to handling dental health problems in the Assisted Village of Mekarsaluyu Village, Cimenyan District, Bandung Regency. Counseling on the potential of natural ingredients, especially kitchen spices as an alternative to dental health therapy with an audio-visual approach to PKK mothers in the fostered village has been successfully carried out with enthusiasm and high interest.

Keywords: education, fostered villages, health, kitchen spices, teeth

\section{Pendahuluan}

Gambaran aksesibilitas Desa Mekarsaluyu, Kecamatan Cimenyan, Kabupaten Bandung. Akses utama menuju Desa Mekarsaluyu adalah melalui Jl. Cikutra dan Jl. Bojong Koneng. Maka dapat disimpulkan bahwa Desa Mekarsaluyu terletak di daerah strategis, yaitu dekat dengan perkotaan, kawasan pendidikan, dan kawasan wisata. Jumlah kependudukan pada Desa Mekarsaluyu, Kecamatan Cimenyan, Kabupaten Bandung berdasarkan klasifikasi jenis kelamin dan kepercayaan. Berdasarkan diagram di atas, bahwa penduduk Desa Mekarsaluyu hampir berimbang antara jenis kelamin perempuan dan pria dan agama/kepercayaan mayoritas penduduk Desa Mekarsaluyu adalah Agama Islam. Mayoritas penduduk Desa Mekarsaluyu memiliki mata pencaharian sebagai Petani dan Buruh Tani. Selain petani, mata pencaharian penduduk Desa Mekarsaluyu adalah pedagang, tenaga pertukangan ("Profil Potensi Desa Desa Mekarsaluyu,”). Keragaman karakteristik fisik lingkungan. Seperti adanya Sungai, tanaman Bambu di sepanjang sungai, variasi dari fungsi lahan yang beragam (kebun pertanian, tanah kosong tak tergarap, pemukiman, peternakan). Suasana Lingkungan tidak tertata, terkesan kumuh. Saluran pembuangan air hujan kurang memadai, sehingga merusak jalan kendaraan dan halaman rumah masyarakat. Desa tidak disertai tempat pengolahan sampah rumah tangga di lingkungan RT. Kondisi jalan akses (gang) menuju rumah-rumah yang ada di bagian bawah kawasan kurang aman dan nyaman, disertai penerangan gang yang kurang memadai. Secara visual suasana jalan/gang yang kurang asri berkesan gersang dan kurang rapi. Tidak adanya fasilitas umum, balai kesehatan, ruang bermain anak dan ruang interaksi sosial 
bagi masyarakat. Kuantitas dan kualitas hunian masih ada yang kurang memenuhi persyaratan untuk kesehatan kenyaman tinggal dan terhadap kesehatan lingkungan.

Pandemi global virus Covid-19 telah berlangsung selama 2 tahun, kondisi tersebut menyebabkan masyarakat perlu melakukan beberapa adaptasi dan perubahan perilaku, yaitu harus tetap menjaga kesehatan tubuhnya (Ciotti et al., 2020). Selain kesehatan secara umum, kesehatan gigi pun menjadi bagian penting yang harus dijaga kebersihan dan kesehatannya agar sistem kekebalan tubuh kita secara menyeluruh tetap optimal. Gigi dan mulut merupakan pintu gerbang masuknya kuman penyakit. (Kemenkes RI, 2018). Oleh karena itu, penting bagi setiap orang di semua kalangan untuk menjaga kebersihan dan kesehatan gigi dan mulut (Azizah, 2021). Untuk menjaga kesehatan gigi dan mulut di masa pandemi ini, bisa dilakukan dari rumah karena alam memiliki banyak kekayaan yang bisa dimanfaatkan untuk kesehatan. Kehadiran alam sekitar sangat membantu masyarakat yang hidup dari alam. Kesehatan akan terjaga apabila masyarakat tahu bahwa alam sekitar memberikan manfaat kesehatan yang luar biasa. Salah satu contohnya dari mengkonsumsi bahan-bahan yang sering digunakan sebagai bumbu dapur.

Bumbu dapur tersebut mempunyai zat-zat yang baik untuk kesehatan, sebagai contohnya yaitu larutan garam. Pada konsentrasi tinggi dapat mematikan pertumbuhan bakteri dengan cara menarik air dari sel bakteri tersebut sehingga menyebabkan lisis. Dengan kondisi kesehatan gigi dan mulut yang baik akan menunjang kesehatan tubuh secara menyeluruh. Maka dari itu, dengan rutin menjaga kesehatan gigi dan mulut (Sholekhah, 2019), kita dapat terhindar dari masalah gigi sehingga dapat mengikuti anjuran dan himbauan pemerintah untuk tetap dirumah agar terhindar dari penyebaran virus covid-19.

Bumbu dapur memiliki banyak manfaat dan khasiat untuk menjaga kesehatan tubuh dalam masa pandemi seperti sekarang. Bumbu dapur yang mudah didapatkan, bisa menjadi salah satu pilihan untuk digunakan sebagai peningkat atau mempertahankan imunitas tubuh dengan baik. Sehingga tubuh lebih terjaga, dan terlindungi dari Covid-19. Salah satunya asam jawa yang memiliki fitokimia seperti tannin, flavonoid, alkaloid, cyanogenic glycoside, anthraquinone, dan berbagai senyawa aromatik yang merupakan metabolit sekunder dari bahan ini (Kartikawati dkk., 2020). Berperan sebagai penghambat mekanisme adhesi bakteri pada sel host, dengan menyebabkan penurunan jumlah atau aktifitas protein-protein yang terlibat dalam proses adhesi bakteri tersebut, baik dari sisi molekul adhesi atau dari sisi reseptor pada sel host (Putri, 2014). 
Bumbu dapur pula bisa menjadi salah satu alternatif bahan alami dalam menjaga kesehatan gigi dan mulut dalam masa pandemi yang sangat penting. Seperti serai yang bisa dimanfaatkan sebagai obat kumur. Penelitian menunjukkan bahwa ekstrak air dan ekstrak etanol daun dan batang serai memiliki daya hambat terhadap bakteri Streptococcus mutans. Ekstrak daun dan batang serai dilaporkan mengandung saponin, flavonoid, polifenol, alkaloid, dan minyak atsiri (Munawaroh \& Handayani, 2010). Kandungan-kandungan tersebut bisa menjaga kesehatan mulut dari bakteri Streptococcus mutans dan mencegah dari berbagai masalah mulut (Nambiar \& Matela, 2012).

Bakteri yang paling berperan dalam menyebabkan karies adalah Streptococcus mutans yang merupakan flora normal rongga mulut. Serai (Cymbopogon citratus) adalah salah satu bahan alam yang dapat digunakan untuk pengobatan tradisional. Salah satu khasiat serai adalah sebagai obat kumur. Pada umumnya memanfaatkan batang dan daun serai yang biasa digunakan untuk bumbu penambah aroma masakan, sebagai obat untuk meredakan sakit gigi. Caranya dengan merebus rebus 40 gram serai segar dengan 2 gelas air sampai airnya tersisa setengah kemudian cairan tersebut digunakan untuk berkumur selama beberapa menit. Penelitian menunjukkan bahwa ekstrak air dan ekstrak etanol daun dan batang serai memiliki daya hambat terhadap bakteri Streptococcus mutans (Erlyn, 2016).

Masyarakat sebaiknya diberikan informasi lebih jelas mengenai khasiat yang terkandung dalam tanaman yang digunakan sebagai bumbu dapur. Adanya media informasi bagi masyarakat agar bisa memahami bahwa kesehatan itu penting, terutama kesehatan yang bisa didapatkan dari kekayaan alam sekitar karena masa pandemi sekarang, masyarakat memiliki keterbatasan untuk mendapatkan bahan-bahan dari luar. Melalui program edukasi diharapkan dapat meningkatkan pengetahuan dan kesadaran masyarakat akan pentingnya menjaga kesehatan gigi dan mulut dan dapat berpartisipasi secara aktif dalam meningkatkan upaya pelihara diri. Selain itu dengan edukasi, seseorang bisa mengupayakan diri dalam usaha pencegahan. Oleh karena itu, diharapkan makalah ini dapat membantu masyarakat agar dapat mengetahui dan menyadari pemanfaatan bumbu dapur untuk kebutuhan kesehatan masyarakat itu sendiri.

\section{Metode}

Metode pelaksanaan kegiatan dalam melaksanakan solusi untuk mengatasi permasalahan dijabarkan dalam beberapa tahap pelaksanaan. Solusi untuk membantu memecahkan masalah 
Jurnal Abdimas Kartika Wijayakusuma ISSN 2716-3512 (Online) ISSN 2721-0367 (Print)
This work is licensed under a Creative Commons Attribution-ShareAlike 4.0 International License.

pengetahuan mengenai kesehatan gigi terutama alternatif penanggulangan penyakit gigi menggunakan bahan dapur yang bersumber dari alam sekitar. Selain memberikan manfaat pada masyarakat yang menjadi peserta edukasi kegiatan ini juga memberikan wadah kepada dokter gigi dan dokter gigi spesialis konservasi gigi untuk menyampaikan hasil penelitian mengenai bahan alam yang dapat dimanfaatkan oleh masyarakat sebagai bumbu dapur yang dapat dimanfaatkan sebagai penanganan masalah kesehatan gigi.

Pendekatan yang dilakukan pada pengabdian kepada masyarakat ini akan berhasil dengan efektif dan efisien karena dilakukan secara berkesinambungan dari hulu ke hilir. Edukasi dengan tema bumbu dapur yang berasal dari alam sekitar sebagai alternatif penanganan masalah kesehatan gigi di Desa Binaan Wilayah Desa Mekarsaluyu Kecamatan Cimenyan, Kabupaten Bandung. Edukasi online adalah suatu proses belajar mengajar yang memakai jaringan internet yang dapat memudahkan penggunanya terhubung tanpa keterbatasan waktu dan tempat dengan siapa saja (Azizah, 2021).

\section{Hasil dan Diskusi}

Edukasi pada masyarakat dilakukan dengan metode yang bertahap, yaitu materi edukasi disusun oleh tim.. Tim pelaksana terdiri dari dosen pembimbing dan mahasiswa yang terlibat pada program ini yaitu mahasiswa pada Program Pendidikan tahap sarjana dan tahap profesi Kedokteran Gigi Unjani Bahan alam yang dapat dimanfaatkan oleh masyarakat sebagai bumbu dapur yang dapat dimanfaatkan sebagai penanganan masalah kesehatan gigi. Mahasiswa terlibat langsung dalam bentuk kontribusi pada masyarakat yaitu memberikan edukasi dalam upaya merubah kebiasaan masyarakat melalui upaya pembangunan desa binaan mandiri.

Materi edukasi disampaikan melalui presentasi dalam bentuk power point, leaflet dan video yang disusun oleh mahasiswa, seperti pada Gambar 1 dan 2 (Prasko dkk., 2016).

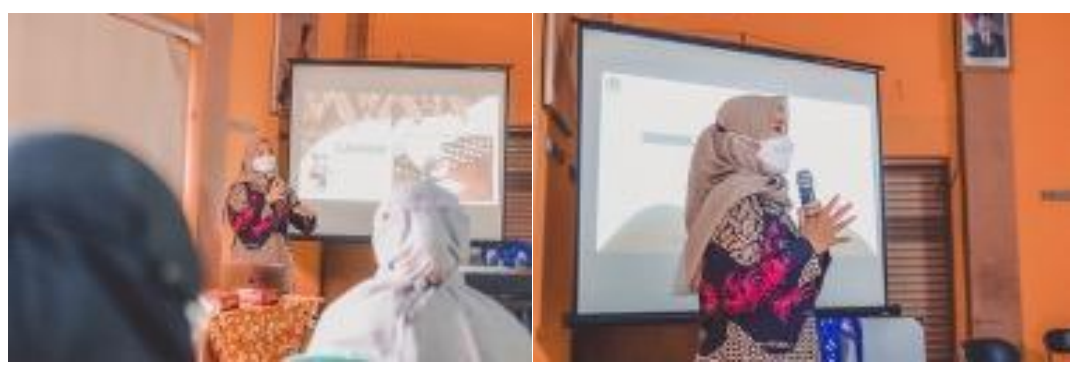

Gambar 1. Edukasi dalam bentuk power point

Volume 3, Nomor 1, Maret 2022| 63

Peran Program Merdeka Belajar Kampus Merdeka dalam Pengembangan Desa Binaan Melalui Edukasi Potensi Bahan Alam Bumbu Dapur Sebagai Terapi Alternatif Pada Penyakit Gigi

Atia Nurul Sidiqa, Asih Rahaju, Zwista Yulia Dewi, Ratih Widyasari, Hartanto Endrowahyudi, Badi Soerachman

https://doi.org/10.26874/jakw.v3i1.170 
Jurnal Abdimas Kartika Wijayakusuma ISSN 2716-3512 (Online) ISSN 2721-0367 (Print)
This work is licensed under a Creative Commons Attribution-ShareAlike 4.0 International License.

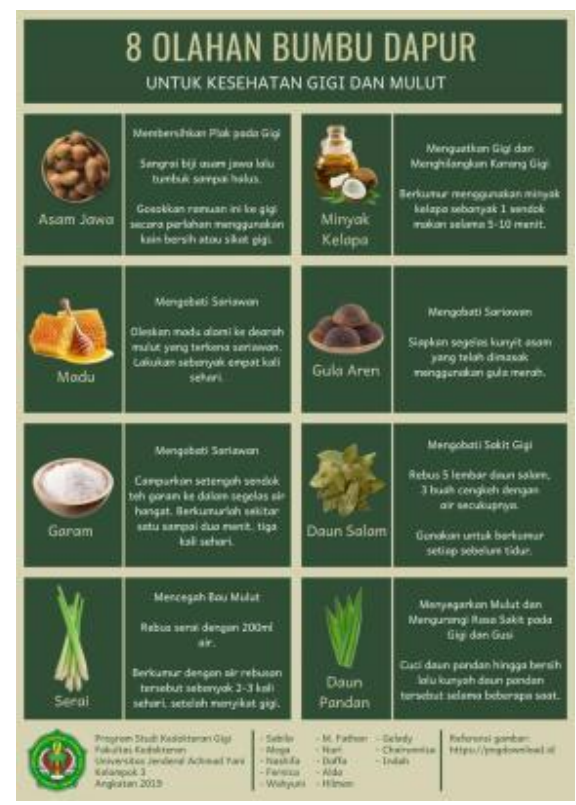

CC BY SA

Gambar 2. Media edukasi dalam bentuk leaflet

Penyampaian materi dan informasi edukasi dilakukan pada ibu-ibu PKK Desa Mekarsaluyu, Kecamatan Cimenyan, Kabupaten Bandung. Materi edukasi berupa bumbu dapur yang banyak digunakan oleh ibu-ibu. Pendampingan dan dukungan pada saat proses edukasi yang dilakukan selain dihadiri oleh Kepala Desa yang pada pelaksanaan dapat sekaligus membuka acara dan memberikan sambutan dalam bentuk dukungan kegiatan Kerjasama dengan desa binaan seperti pada Gambar 3. Dukungan penuh disampaikan pula oleh Kepala Desa Binaan setelah bersama-sama mengikuti kegiatan edukasi ini yang tentunya dapat menunjang peningkatan pengetahuan ibu-ibu PKK mengenai potensi bahan alam yang dapat digunakan sebagai bahan alternatif terapi kesehatan gigi.

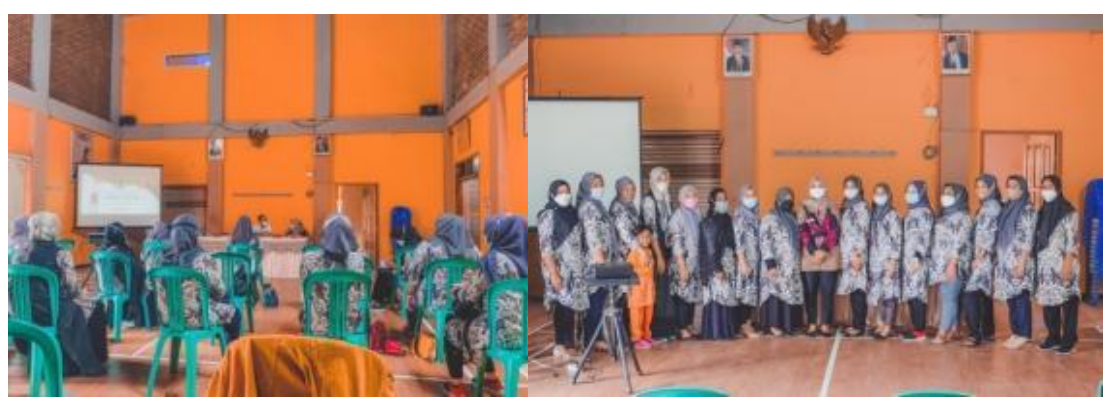

Gambar 3. Dukungan kegiatan bersama pemangku kebijakan

Volume 3, Nomor 1, Maret 2022| 64 Peran Program Merdeka Belajar Kampus Merdeka dalam Pengembangan Desa Binaan Melalui Edukasi Potensi Bahan Alam Bumbu Dapur Sebagai Terapi Alternatif Pada Penyakit Gigi 


\section{Kesimpulan}

Edukasi mengenai potensi bahan alam terutama bumbu dapur sebagai alternatif terapi kesehatan gigi dengan pendekatan melalui metode audio visual pada Ibu-ibu PKK di di Desa Binaan Wilayah Desa Mekarsaluyu Kecamatan Cimenyan, Kabupaten Bandung telah berhasil dilakukan dengan antusias dengan minat yang tinggi. Manfaat jangka panjang diharapkan ibu yang merupakan lingkar terdekat masyarakat dapat memberikan solusi penanganan darurat penyakit gigi di keluarga. Pola hidup sehat dengan pengetahuan mengenai potensi bahan alam sebagai salah satu penanganan penyakit gigi menjadi salah satu luaran desa binaan.

\section{Ucapan Terima Kasih}

Ucapan terima kasih disampaikan kepada Direktorat Jenderal Pendidikan Tinggi Kemendikbudristek yang telah mendanai kegiatan ini dalam skema Bantuan Pendanaan Program Penelitian Kebijakan Merdeka Belajar Kampus Merdeka dan Pengabdian Masyarakat (MBKM) Berbasis Hasil Penelitian Perguruan Tinggi Swasta, Universitas Jenderal Achmad Yani (UNJANI) Tahun 2021.

\section{Referensi}

Azizah, A.Y. 2021. Edukasi Online Terhadap Perubahan Perilaku Menjaga Kebersihan Gigi Pada Mulut Selama Masa Pandemi. Jurnal Ilmiah PANNMED (Pharmacist, Analyst, Nurse, Nutrition, Midwivery, Environment, Dentist) 16, 224-228.

Ciotti, M., Ciccozzi, M., Terrinoni, A., Jiang, W.C., Wang, C.B., Bernardini, S. 2020. The COVID-19 pandemic. Critical Reviews in Clinical Laboratory Science, 57, 365-388.

Erlyn, P. 2016. Efektivitas Antibakteri Fraksi Aktif Serai (Cymbopogon citratus) terhadap Bakteri Streptococcus mutans. Syifa' MEDIKA: Jurnal Kedokteran dan Kesehatan, 6(2), 111-125.

Kartikawati, E., Andri Deswati, D. \& Pramudita, B. 2020. Uji Efek Analgetik Ekstrak Etanol Daun Asam Jawa (Tamarindus indica L) pada Mencit Putih Jantan Galur Swiss Webster. Jurnal Sabdariffarma, 1(2), 11-18.

Kemenkes RI. 2018. Laporan Hasil Riset Kesehatan Dasar (Riskesdas) Indonesia tahun 2018. Riset Kesehatan Dasar 2018.

Munawaroh, S. \& Handayani, P.A. 2010. Ekstraksi Minyak Daun Jeruk Purut (Citrus hystic D.C) dengan Pelarut Etanol dan N-Heksana. Jurnal Kompetensi Teknik, 2(1), 73-78. 
Jurnal Abdimas Kartika Wijayakusuma ISSN 2716-3512 (Online) ISSN 2721-0367 (Print)
This work is licensed under a Creative Commons Attribution-ShareAlike 4.0 International License. CC BY SA

Profil Potensi Desa - Desa Mekarsaluyu [WWW Document], n.d. URL https://mekarsaluyu.desa.id/artikel/2014/4/30/profil-potensi-desa (accessed 1.13.22).

Putri, C.R.H. 2014. Potensi dan Pemanfaatan Tamarindus Indica Dalam Berbagai Terapi. Jurnal Ilmiah Kedokteran Wijaya Kusuma, 3 (2), 40-54.

Sholekhah, N.K. 2019. Efektivitas Berkumur Larutan Garam terhadap Jumlah Koloni Streptococcus Mutans Dalam Saliva. Jurnal Kesehatan Gigi 8(1), 17-20.

Prasko, Sutomo, B. \& Santoso, B. 2016. Penyuluhan Metode Audio Visual Dan Demonstrasi Terhadap Pengetahuan Menyikat Gigi Pada Anak Sekolah Dasar. Jurnal Kesehatan Gigi, 3(2), 53-57.

Nambiar, V.S. \& Matela H. 2012. Potential Functions of Lemon Grass (Cymbopogon citratus) in Health and Disease. International Journal of Pharmaceutical \& Biological Archives, 3(5), 1035-1043. 